\title{
The role of CXCR5 and its ligand CXCL13 in the compartmentalization of lymphocytes in thyroids affected by autoimmune thyroid diseases
}

\author{
G Aust, D Sittig, L Becherer ${ }^{1}$, U Anderegg ${ }^{2}$, A Schütz ${ }^{3}$, L Lamesch ${ }^{1}$ and E Schmücking \\ Institute of Anatomy, ${ }^{1}$ Department of Surgery, ${ }^{2}$ Department of Dermatology and ${ }^{3}$ Institute of Pathology, University of Leipzig, Leipzig, Germany \\ (Correspondence should be addressed to G Aust, University of Leipzig, Institute of Anatomy, Ph-Rosenthal-Strasse 55, Leipzig, O4103, Germany; \\ Email: ausg@medizin.uni-leipzig.de)
}

\begin{abstract}
Objective: Graves' disease (GD) and Hashimoto's thyroiditis (HT) are characterized by lymphocytic infiltrates partly resembling secondary lymphoid follicles in the thyroid. CXCR 5 and its ligand CXCL13 regulate compartmentalization of B- and T-cells in secondary lymphoid organs. The aim of the study was to elucidate the role of this chemokine receptor-ligand pair in thyroid autoimmunity. Methods: Peripheral blood and thyroid-derived lymphocyte subpopulations were examined by flow cytometry for CXCR 5. CXCR 5 and CXCL13 cDNA were quantified in thyroid tissues by real-time RT-PCR. Results: We found no differences between the percentages of peripheral blood CXCR $5^{+} \mathrm{T}-$ and B-cells in GD patients $(n=10)$ and healthy controls $(n=10)$. In GD patients, the number of memory CD4 $4^{+}$cells expressing CXCR 5 which are functionally characterized as follicular B helper T-cells is higher in thyroidderived $(18 \pm 3 \%)$ compared with peripheral blood T-lymphocytes $(8 \pm 2 \%)$. The highest CXCL13 mRNA levels were found in HT $\left(n=2,86.1 \pm 1.2 \mathrm{zmol}\left(10^{-21} \mathrm{~mol}\right) \mathrm{cDNA} / \mathrm{PCR}\right)$ followed by GD tissues $(n=16$, $9.6 \pm 3.5)$. Only low amounts were determined in thyroid autonomy (TA) $(n=11)$ thyroid tissues, irrespective of whether the autonomous nodule $(0.5 \pm 0.1)$ or the surrounding normal tissue $(1.8 \pm 0.7)$ had been analyzed. The same differences were found for CXCR 5 (HT: 179.1 6.8 ; GD: 17.4 \pm 10.6 ; TA $_{\text {nodule: }}$ : $\left.0.8 \pm 0.5 ; \mathrm{TA}_{\text {normal }}: 4.4 \pm 3.6\right)$. In GD, there is a correlation between CXCL13 and CXCR 5 mRNA levels and the number of focal lymphocytic infiltrates and germinal centers as well as anti-thyroperoxidase but not anti-TSH receptor autoantibodies.

Conclusions: CXCR 5 and CXCL13 play an essential role in maintaining B- and T-cells in lymphocytic infiltrates and ectopic follicles in thyroid tissue from patients affected by autoimmunity.
\end{abstract}

European Journal of Endocrinology 150 225-234

\section{Introduction}

Lymphoid follicles are usually observed in secondary lymphoid tissues and organs, and are essential structures for normal immune responses in which antigenspecific B- and T-cells are expanded against antigens. Chemokines and their receptors are involved in compartmentalization of these follicles establishing spatially and functionally segregated microenvironments. The role of CXCR 5 and its unique ligand CXCL13 (BCA-1; B-cell attracting chemokine 1) in the organization of lymphoid follicles is clearly demonstrated in genetargeted mice (1-3). Interaction between CXCR 5 and CXCL13 is especially required for B-cell architectural organization (4). In CXCL13-deficient mice, B-cells failed to organize in polarized follicular clusters and instead appeared as a ring of cells at the perimeter of T-cell areas.

Naive B-cells localize in a CXCR5-dependent manner in the B-cell zone of the normal lymphoid follicle where CXCL13 is produced by stromal cells mainly representing follicular dendritic cells. In addition to Bcells, CXCR5 is expressed in a subset of memory $\mathrm{CD}^{+}{ }^{+}$T-cells termed follicular B-helper T-cells $\left(\mathrm{T}_{\mathrm{FH}}\right)$ that migrate into the B-cell zone to support immunoglobulin production (5-8).

In addition to lymphoid follicles located in secondary lymphoid tissues and organs, follicle formation is observed ectopically in chronic inflammatory sites or tissues affected by autoimmunity. Here, they recapitulate the structure of normal secondary follicles. Ectopic lymphoid follicles have been demonstrated in synovium from chronic arthritis patients $(9,10)$, in the salivary gland from patients with Sjogren's syndrome (11), and in intestinal specimens from patients with colitis ulcerosa (12). CXCL13 and CXCR5 are expressed in these irregular aggregates, suggesting that both may play a role in aberrant lymphoid tissue.

In autoimmune thyroid diseases, ectopic lymphoid follicles have been demonstrated in thyroid tissues from patients with Hashimoto's thyroiditis (HT) as well as Graves' disease (GD). Lymphocytic infiltration 
progressively replaces thyroid follicles in HT. A spectrum of lymphocytic infiltration is observed in GD from the minimal numbers of immune cells in some thyroids (diffuse infiltration) to focal thyroiditis in others (13). In contrast to HT, most of the thyroid in GD remains intact except for signs of hyperfunction. In most cases, there is a direct relationship between the extent of lymphocytic infiltration in GD tissues and the percentage of germinal center (GC) formation. The degree of lymphocytic infiltration was related to the titers of anti-thyroglobulin and anti-thyroperoxidase (TPO) antibodies (13). T-cells were mostly scattered individually or in small groups between the follicles; however, they mainly formed clusters in the severely infiltrated group (14).

Recent studies suggest that chemokines and their receptors are not only involved in the initiation and maintenance of the autoimmune process in HT and GD (15-18), but are also capable of organizing and sustaining lymphoid follicles in the thyroid $(17,19)$. Armengol et al. (17) detected CXCL13 mRNA in thyroids affected by autoimmunity, but not in normal thyroid. We published the first quantitative results on CXCL13 mRNA levels in autoimmune and non-autoimmune thyroid tissues (20), which were very recently confirmed by others (19). All studies have shown that the presence of chemokines in most thyroids is largely restricted to lymphocytic cell infiltration. However, thyrocytes and thyroid-derived fibroblasts are also able to express some chemokines (21-25), and may thus perturb the immune process.

The aim of our study was to evaluate whether any difference in CXCR 5 expression between thyroid-derived lymphocytes (TLs) and peripheral blood lymphocytes (PBLs) within memory $\mathrm{CD}^{+}$and $\mathrm{CD}^{+}$T-cell and B-cell fractions had occurred. Moreover, we clarified the question of whether intrathyroidal CXCR5 and CXCL13 mRNA levels were correlated with the presence and extension of focal lymphocytic infiltration in thyroids affected by GD and HT. In contrast to Armengol et al. (19), who included multinodular goiter tissues as controls, we compared the results with thyroid tissue from patients with non-autoimmune thyroid autonomy (TA). TA nodules, nearly completely free of any lymphocyte, are a useful background control; normal, nodule-surrounding TA tissues mimic the normal thyroid situation. In addition to Armengol et al. (19), we also quantified CXCR 5 mRNA levels as an extent of the number of $\mathrm{CXCR} 5^{+}$cells.

Our results demonstrated that CXCR 5 and its ligand are indeed involved in the organization and extension of lymphocytic infiltrates and ectopic follicles.

\section{Materials and methods}

\section{Patients}

GD $(n=16$, all females, mean age $n$ s.E.M. $35.6 \pm 3.7$ years), HT ( $n=2$, both females, 18 and 34 years) and TA ( $n=11$, five females, $55.7 \pm 5.2$ years) were diagnosed on the basis of clinical, biochemical and immunological characteristics and from scintiscans (Table 1). Thyroid scans using Tc-99m pertechnetate from all patients with unifocal TA showed a single hot nodule and a low uptake in the rest of the thyroid. Hyperthyroidism was confirmed by measurements of serum thyroid-stimulating hormone (TSH), free thyroxine and free triiodothyronine. The diagnosis of GD was also made on a clinical basis, which included the presence of anti-thyroid antibodies, goiter and typical symptoms and signs of thyrotoxicosis. The diagnosis was confirmed by histopathological diagnosis. All GD patients had been treated with anti-thyroid drugs since diagnosis (Table 1).

Antibodies against TSH receptor (TSH-R) (TSH-binding-inhibiting immunoglobulin, TBII) and TPO were measured in serum obtained up to 2 weeks before operation using commercial RIA kits (TRAKhuman DYNOTEST, anti-TPO $\mathrm{n}_{\mathrm{n}}$ DYNOTEST; Brahms Diagnostica $\mathrm{GmbH}$, Berlin, Germany). All GD patients showed positive TBII ( $>2$ IU/l), and 9 out of 16 showed positive anti-TPO antibodies $(>60 \mathrm{U} / \mathrm{ml})$. PBLs of GD patients were investigated prior to surgery. Ten out of the sixteen patients were selected for flow cytometry studies. GD patients with low lymphocytic infiltration and low or negative TPO antibody levels are rare. Thyroid tissues from such patients were taken from our established thyroid tissue bank. Because we needed freshly isolated PBLs and TLs for flow cytometry analysis, the ten other GD patients were included in the present study when they underwent surgery.

Peripheral blood samples from ten normal adults (two male, eight female; mean age 33.7 \pm 2.7 years) without any history of autoimmune disease were used as controls. The study was approved by the local Committee of Medical Ethics, and all patients gave their written consent.

\section{Real-time PCR}

Total cellular RNA was isolated using the QIAGEN total RNA isolation kit (QIAGEN GmbH, Hilden, Germany). cDNA was synthesized from $1 \mu \mathrm{g}$ RNA in a $20 \mu \mathrm{l}$ standard reaction mixture containing 200 U Superscript II RNaseH reverse transcriptase (Invitrogen $\mathrm{GmbH}$, Karlsruhe, Germany).

Quantitative PCR was performed on a Rotorgene (Corbett Research, Mortlake, Australia) real-time machine by using SYBR Green I (Molecular Probes Europe, Leiden, The Netherlands) as a double-strand DNA-specific binding dye and continuous fluorescence monitoring. Amplification was carried out in a total volume of $20 \mu \mathrm{l}$ containing $0.5 \mu \mathrm{mol} / \mathrm{l}$ of each primer, $2.5 \mathrm{mmol} / \mathrm{l} \mathrm{MgCl}_{2}, 1 \mathrm{U}$ Taq Polymerase (Roche), $10 \times$ Taq buffer $(500 \mathrm{mmol} / \mathrm{l} \mathrm{KC1,} 100 \mathrm{mmol} / \mathrm{l}$ Tris $-\mathrm{HC} 1$, $\mathrm{pH}$ 8.3; Roche), $2 \mathrm{mmol} / \mathrm{l}$ of each dNTP, $1 \mu \mathrm{l}$ 1:2000 
Table 1 Sex, age, diagnosis, duration of GD (only GD patients) until enrollment, signs of GO (only GD patients), treatment with anti-thyroid drugs and thyroid histology of patients with GD, HT and TA. In GD the duration of anti-thyroid drug treatment is nearly identical with the duration of the disease.

\begin{tabular}{|c|c|c|c|c|c|c|c|c|c|c|}
\hline Patient & Diagnosis & $\begin{array}{c}\text { Age } \\
\text { (years) }\end{array}$ & Sex & $\begin{array}{c}\text { Duration of } \\
\text { disease (months) }\end{array}$ & $\begin{array}{l}\text { Anti-thyroid } \\
\text { drug treatment }\end{array}$ & $\begin{array}{l}\text { Signs } \\
\text { of GO }\end{array}$ & \multicolumn{2}{|c|}{$\begin{array}{l}\text { Number of } \\
\text { focal infiltrates }\end{array}$} & \multicolumn{2}{|c|}{$\begin{array}{l}\text { Number } \\
\text { of GCs }\end{array}$} \\
\hline 1 & GD & 31 & $\mathrm{~F}$ & $\geq 15$ & Yes & Yes & \multicolumn{2}{|c|}{$-{ }^{a}$} & \multicolumn{2}{|c|}{33} \\
\hline 2 & GD & 29 & $\mathrm{~F}$ & $\geq 15$ & Yes & Yes & \multirow{2}{*}{\multicolumn{2}{|c|}{5}} & \multirow{2}{*}{\multicolumn{2}{|c|}{0}} \\
\hline 3 & GD & 49 & $\mathrm{~F}$ & $\leq 5$ & Yes & Yes & & & 1 & \\
\hline 4 & GD & 29 & $\mathrm{~F}$ & $\leq 5$ & Yes & No & \multicolumn{2}{|c|}{$\begin{array}{c}3 \\
13\end{array}$} & \multicolumn{2}{|c|}{10} \\
\hline 5 & GD & 30 & $\mathrm{~F}$ & $\leq 5$ & Yes & No & \multicolumn{2}{|c|}{$\begin{array}{c}13 \\
5\end{array}$} & \multirow{2}{*}{\multicolumn{2}{|c|}{$\begin{array}{l}2 \\
0\end{array}$}} \\
\hline 6 & GD & 48 & $\mathrm{~F}$ & $\geq 15$ & Yes & Yes & \multicolumn{2}{|c|}{3} & & \\
\hline 7 & GD & 51 & $\mathrm{~F}$ & $\geq 15$ & Yes & Yes & \multicolumn{2}{|c|}{0} & \multicolumn{2}{|c|}{0} \\
\hline 8 & GD & 14 & $\mathrm{~F}$ & $\leq 5$ & Yes & No & \multicolumn{2}{|c|}{22} & \multicolumn{2}{|c|}{6} \\
\hline 9 & GD & 17 & $\mathrm{~F}$ & $\geq 15$ & Yes & No & \multicolumn{2}{|c|}{30} & \multicolumn{2}{|c|}{4} \\
\hline 10 & GD & 69 & $\mathrm{~F}$ & $\leq 5$ & Yes & No & \multicolumn{2}{|c|}{15} & \multicolumn{2}{|c|}{4} \\
\hline 11 & GD & 36 & $\mathrm{~F}$ & $\geq 15$ & Yes & No & \multicolumn{2}{|c|}{29} & \multicolumn{2}{|c|}{0} \\
\hline 12 & GD & 36 & $\mathrm{~F}$ & $\leq 5$ & Yes & Yes & \multicolumn{2}{|c|}{2} & \multicolumn{2}{|c|}{1} \\
\hline 13 & GD & 18 & $\mathrm{~F}$ & $\geq 15$ & Yes & Yes & \multicolumn{2}{|c|}{60} & \multicolumn{2}{|c|}{50} \\
\hline 14 & GD & 25 & $\mathrm{~F}$ & $\geq 15$ & Yes & Yes & \multirow{2}{*}{\multicolumn{2}{|c|}{4}} & \multicolumn{2}{|c|}{0} \\
\hline 15 & GD & 38 & $\mathrm{~F}$ & $\leq 5$ & Yes & Yes & & & & \\
\hline 16 & GD & 50 & $\mathrm{~F}$ & $\geq 15$ & Yes & No & & 2 & & \\
\hline 17 & $\mathrm{HT}$ & 34 & $\mathrm{~F}$ & - & No & - & & a & & \\
\hline 18 & $\mathrm{HT}$ & 18 & $\mathrm{~F}$ & - & No & - & & a & & \\
\hline & & & & & & & $\begin{array}{l}\text { Nodular } \\
\text { tissue }\end{array}$ & $\begin{array}{l}\text { Perinodular } \\
\text { tissue }\end{array}$ & $\begin{array}{l}\text { Nodular } \\
\text { tissue }\end{array}$ & $\begin{array}{l}\text { Perinodular } \\
\text { tissue }\end{array}$ \\
\hline 19 & TA & 58 & M & - & Yes & - & 0 & 0 & 0 & 0 \\
\hline 20 & TA & 52 & $\mathrm{~F}$ & - & No & - & 0 & 10 & 0 & 5 \\
\hline 21 & TA & 70 & $M$ & - & No & - & 0 & 0 & 0 & 0 \\
\hline 22 & TA & 44 & $M$ & - & No & - & 0 & 0 & 0 & 0 \\
\hline 23 & TA & 75 & $M$ & - & No & - & 0 & 1 & 0 & 0 \\
\hline 24 & TA & 38 & $\mathrm{~F}$ & - & Yes & - & 0 & 0 & 0 & 0 \\
\hline 25 & TA & 77 & $\mathrm{~F}$ & - & Yes & - & 0 & 0 & 0 & 0 \\
\hline 26 & TA & 74 & $M$ & - & Yes & - & 0 & 2 & 0 & 0 \\
\hline 27 & TA & 61 & $M$ & - & Yes & - & 0 & 1 & 0 & 0 \\
\hline 28 & TA & 35 & $\mathrm{~F}$ & - & Yes & - & 0 & 3 & 0 & 0 \\
\hline 29 & TA & 29 & $\mathrm{~F}$ & - & Yes & - & 0 & 4 & 0 & 0 \\
\hline
\end{tabular}

${ }^{a}$ Lymphocytic infiltrates replaced the normal thyroid tissue almost completely. 
SYBR Green I dissolved in DMSO and $1 \mu \mathrm{l} 1: 5$ diluted CDNA.

The PCR primers were CXCR 5 sense (5'-tac ccg cta acg ctg gaa atg gac- $\left.3^{\prime}\right)$, antisense $\left(5^{\prime}\right.$-cac ggc aaa ggg caa gat gaa gac-3'), CXCL13 sense (5'-gag gca gat gga act tga gc- $\left.3^{\prime}\right)$ and antisense $\left(5^{\prime}\right.$-ctg ggg atc ttc gaa tgc ta- $\left.3^{\prime}\right)$, or CD18 sense $\left(5^{\prime}\right.$-ggc gca caa gct ggc tga aaa caa- $\left.3^{\prime}\right)$ and antisense (5'-agc gcc cgg atg aca aac gac $\operatorname{tg}^{-3^{\prime}}$ ) respectively. CD18 mRNA was measured in order to quantify leukocytic infiltration (24). Sizes of PCR products were: CXCR5 318 bp; CXCL13 158 bp and CD18 $372 \mathrm{bp}$. Glyceraldehyde 3-phosphatase dehydrogenase (GAPDH) transcripts were measured using a ready-to-use quantitative PCR test kit (Roboscreen Gesellschaft für Molekulare Biotechnologie, Leipzig, Germany) as previously described (26).

The PCR reactions were cycled 40 times after initial denaturation $\left(95^{\circ} \mathrm{C}, 2 \mathrm{~min}\right)$ with the following parameters: denaturation $95^{\circ} \mathrm{C}, 10 \mathrm{~s}$; annealing 60$68^{\circ} \mathrm{C}$, $20 \mathrm{~s}$; extension $72^{\circ} \mathrm{C}$, $30 \mathrm{~s}$. Control reactions for product identification consisted of (i) determining the length of the PCR products by visualization after agarose gel electrophoresis and ethidium bromide staining and (ii) analyzing the melting peaks in comparison with external standards in the PCR machine. The temperature at which all non-specific product had disappeared was determined by melting temperature analysis. The fluorescence signal from SYBR Green I was reduced to background levels at a temperature of $86^{\circ} \mathrm{C}$. In contrast, there was still a high level of SYBR Green I fluorescence at a temperature of $86^{\circ} \mathrm{C}$ in the sample that contained a cDNA template. A meltingtemperature profile was performed for all specific cDNAs and showed an almost identical pattern of melting. Consequently, a temperature of $86^{\circ} \mathrm{C}$ was selected as the optimum for CXCR5, CXCL13 and CD18 cDNA.

External cDNA standards were constructed by cloning of PCR fragments into pGEM-T vector (Promega, Mannheim, Germany). The PCR fragments were generated by RT-PCR with the same primers as described above. Ligated fragments were transformed into JM-109-competent cells, and plasmid DNA was prepared by using the Plasmid Mini Kit (Qiagen, Hilden, Germany). Concentrations of standards were determined by measuring the OD at $260 \mathrm{~nm}$. Amounts were calculated from a reference curve obtained from the simultaneously processed standard curve. Data are expressed as zeptomol (zmol; $10^{-21} \mathrm{~mol}$ ) cDNA per attomol $\left(10^{-18} \mathrm{~mol}\right)$ of GAPDH cDNA, which was calculated from the same cDNA sample.

\section{Identification of lymphocytic infiltrates and GCs}

Paraffin sections stained with hematoxylin and eosin (HE) were screened for focal lymphocytic infiltration. An infiltrate was defined as an accumulation of lymphocytes taking up more than $0.1 \mathrm{~mm}^{2}$ at a thyroid section. GCs were identified in HE sections by their typical architecture and confirmed by staining for CD23, a marker of a subpopulation of follicular dendritic cells (27). The number of focal lymphocytic infiltrates and GCs was counted within an area of $226 \mathrm{~mm}^{2}$.

\section{Isolation of cell populations}

PBLs were isolated using Ficoll density gradient centrifugation. Thyroid samples were obtained during the operation. Fat and connective tissue were removed immediately. TLs were isolated after mechanical disaggregation of the tissue in PBS. Free cells were subjected to Ficoll density gradient centrifugation.

\section{Chemokine receptor analysis in flow cytometry}

Directly fluorochrome-labeled monoclonal antibodies were supplied by R\&D Systems GmbH Wiesbaden, Germany (CXCR 5-PE, CCR7-PE, CD4-FITC, CD8-FITC), BD Biosciences Europe, Heidelberg, Germany (CD4-CyChrome, CD8-PerCP, CD19-PerCP, CD45R0-FITC, CD62L-FITC), and DakoCytomation GmbH, Hamburg, Germany (CD3-RPE/Cy5).

TLs or PBLs $\left(3 \times 10^{5}\right)$ were incubated with monoclonal antibodies for two- or three-color staining at the desired concentration for $25 \mathrm{~min}$ at $4{ }^{\circ} \mathrm{C}$. The following combinations of monoclonal antibodies were used: (i) CXCR5-PE, CD3-RPE/Cy5, CD8-FITC or CD4FITC, (ii) CXCR5-PE, CD3-RPE/Cy 5 or CD8-PerCP or CD4-Cy-Chrome, CD45R0-FITC, (iii) CXCR5-PE, CD3RPE/Cy 5 or CD19-PerCP, CD62L-FITC, and (iv) CCR7$\mathrm{PE}$, CD3-PerCP/Cy5, CD62L-FITC. The cells were washed three times in PBS/1\% fetal calf serum $/ 0.1 \%$ sodium azide and analyzed by flow cytometry (FACSscan; Becton Dickinson, Mountain View, CA, USA) using electronic gating on lymphocytes (in some experiments by gating on $\mathrm{CD}^{+}, \mathrm{CD}^{+}$or $\mathrm{CD} 8^{+}$lymphocytes) and compensation. Isotype-matched directly labeled irrelevant monoclonal antibodies (Dako) were used as negative controls; 15000 cells over the forward-scatter threshold were analyzed.

\section{Immunohistology}

Frozen thyroid tissue samples were sectioned and fixed in $2 \%$ paraformaldehyde for $10 \mathrm{~min}$ at $4{ }^{\circ} \mathrm{C}$. Endogenous peroxidase was quenched in $0.3 \% \mathrm{H}_{2} \mathrm{O}_{2} /$ methanol for $30 \mathrm{~min}$. Non-specific antibody-binding sites were blocked with 3\% normal goat serum for $20 \mathrm{~min}$. Next, the CD23 monoclonal antibody (Dako) was applied to tissue sections for $1 \mathrm{~h}$ at room temperature. Subsequently, biotinylated goat anti-mouse IgG and streptavidin-horseradish peroxidase (Vector Laboratories, Inc. Burlingame, CA, USA) were added in sequence. Diaminobenzidine (Vector) was used as the chromogen. 


\section{Statistics}

The comparison between the groups was performed using the Mann-Whitney test. Unless otherwise stated, the data are expressed as means \pm S.E.M. The Spearman test was used for correlation analysis.

\section{Results}

\section{Lymphocytic infiltrates and GCs within thyroid tissues}

A high degree of cellular organization is acquired by the tissue-infiltrating lymphocytes in HT and GD. In GD thyroids, T- and B-cells are seldom arranged as diffuse infiltrates without specific microstructures (Fig. 1A). In most GD thyroids, B- and T-cells formed clusters, referred to here as focal lymphocytic infiltrates, lacking GCs (Fig. 1B). The number of these lymphocytic infiltrates varied significantly between the various patient groups (number $/ 226 \mathrm{~mm}^{2}$; mean \pm S.E.M.): GD tissues $14 \pm 4$, TA normal tissues $2 \pm 1$; TA nodular tissues no lymphocytic infiltrates. The number of lymphocytic infiltrates within normal TA tissue seems to represent the normal background reaction. Lymphocytes were abundant in the two HT tissues (Fig. 1D). In these HT thyroids and a subgroup of GD thyroids (10 out of 16), the autoimmune process additionally induces the formation of GCs that were easy identified in HE- and CD23-stained sections (Fig. 1C-E). GCs were found only in one TA tissue.

A subpopulation of follicular dendritic cells was identified by immunohistological staining for CD23 (27). Tissues with lymphocytic infiltrates without $\mathrm{CD} 23^{+}$follicular dendritic cells lacked GCs, indicating that these structures were different from primary follicles. The selective presence of $\mathrm{CD}_{2} 3^{+}$follicular
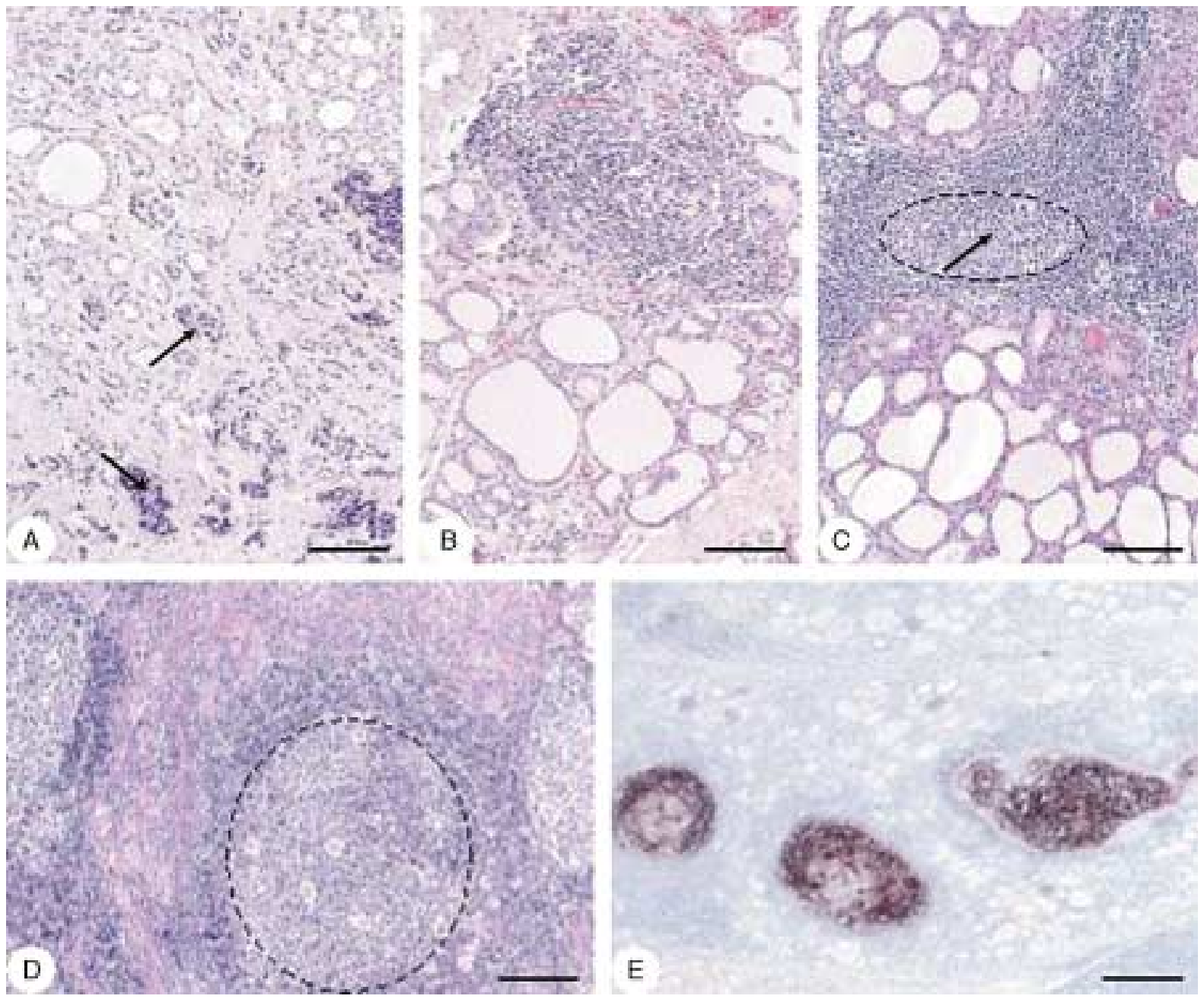

Figure 1 Pattern of lymphoid organization in thyroids affected by GD and HT. (A) Lymphocytes were diffusely distributed throughout the thyroid (arrows) in few GD patients. (B) We found formed focal lymphocytic infiltrates lacking GC reactions in most GD tissues. (C) Ectopic follicles with typical GCs (arrow) had formed in a subset of GD patients (10 out of 16). (D) In HT, thyroid tissues were often replaced by many large ectopic follicles. (E) CD23 characterizes a subpopulation of follicular dendritic cells located in GCs (HT patient). Scale bar $100 \mu \mathrm{m}$. 
dendritic cells in GCs indicated that these cells are not a regular component of the thyroid tissue.

For further analysis, GD patients were divided into two groups according to the number of focal lymphocytic infiltrates (high: $>5 / 226 \mathrm{~mm}^{2}$; low: $\leq 5 / 226 \mathrm{~mm}^{2}$ ) and the number of GCs (with/without).

\section{CXCR 5 mRNA levels in thyroid tissues (Fig. 2)}

All thyroid tissues of HT and GD patients investigated were CXCR5- and CXCL13 mRNA-positive, while we frequently failed to obtain any signal, especially from thyroid nodule samples from TA patients. CXCR 5 mRNA levels strongly correlated with the number of focal lymphocytic infiltrates and GCs, weakly with TPO, but not with TBII antibodies in GD (Table 2).

The highest CXCR 5 mRNA levels were determined in thyroid tissues from the two HT patients (172.4 and $185.9 \mathrm{zmol}$ CXCR5 cDNA/PCR) who also showed the highest numbers of lymphocytic infiltrates and GCs.

GD patients with high numbers of lymphocytic infiltrates $\left(>5 / 226 \mathrm{~mm}^{2}\right)$ showed a significantly higher CXCR 5 mRNA level (zmol CXCR 5 cDNA/PCR, mean \pm S.E.M., $36.3 \pm 17.2$ ) than patients with few or no lymphocytic infiltrates $(1.1 \pm 0.9 ; P<0.001)$. The same is true for the number of GCs. In GD, the CXCR 5 mRNA levels were not significantly different between patients without $(7.0 \pm 2.6)$ and with $(25.5 \pm 16.3)$ signs of Graves' ophthalmopathy (GO) and between patients with long ( $>15$ months; $13.7 \pm 5.9)$ or short ( $<5$ months; $4.5 \pm 1.8)$ anti-thyroid drug treatment.

CXCR 5 mRNA levels of tissues from GD patients with high numbers of lymphocytic infiltrates or GCs differed significantly from that of both tissues of TA patients
$(P<0.01)$. CXCR5 mRNA levels were five times lower in autonomous nodules than in the corresponding quiescent tissue from TA patients.

\section{CXCL13 mRNA levels in thyroid tissues}

The two HT patients also showed the highest CXCL13 mRNA levels (zmol CXCL13 cDNA/PCR; 74.0 and 98.1). In GD, tissues with GC reactions have 10- to 20-fold transcription levels for CXCL13 compared with tissues without GCs. Tissues with high numbers of focal lymphocytic infiltrates $\left(>5 / 226 \mathrm{~mm}^{2}\right)$ showed ten times the CXCL13 mRNA level (mean士 S.E.M. 17.5 \pm 5.5$)$ compared with patients with no or low numbers of lymphocytic infiltrates (1.9 \pm 1.4 ; $P<0.001)$ or normal tissue from TA patients (1.8 \pm 0.7$)$. CXCL13 mRNA levels differed significantly between autonomous single adenomas and the corresponding normal tissue $(P<0.005)$ from TA patients.

In GD patients, the CXCL13 mRNA level did correlate with the number of focal lymphocytic infiltrates and GCs, or with the level of TPO but not TBII antibodies for that matter (Table 2). The CXCL13 mRNA levels were not significantly different between GD patients without $(9.6 \pm 4.7)$ and with $(9.7 \pm 5.4)$ signs of GO and between GD patients with long $(>15$ months; $13.7 \pm 5.9)$ or short $(<5$ months; $4.5 \pm 1.8)$ anti-thyroid drug treatment.

\section{Flow cytometry}

PBLs differed from their thyroid-derived counterparts in terms of resting-state and lymph-node-homing capabilities, i.e. CD62L, CD45R0 and CCR7 expression. CD62L
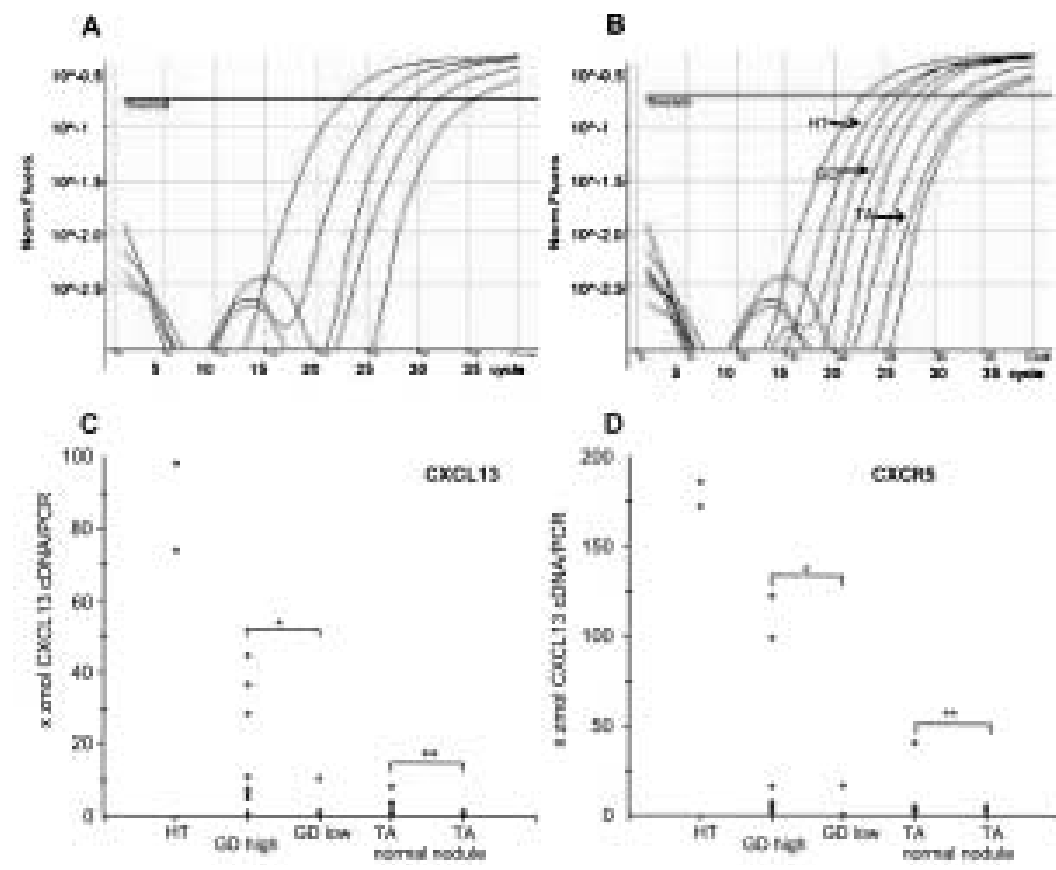

Figure 2 Quantification of CXCR5 and CXCL13 mRNA in thyroid tissues. Real-time PCR. (A) Amplification blot showing 10-fold dilutions of the standard for CXCR13 (1000-0.1 zmol CXCR13 CDNA/PCR). (B) Amplification blot showing the standard for CXCR13 CDNA as in (A), but typical Hashimoto's thyroiditis (HT), Graves' disease (GD), and thyroid autonomy (TA, nodule surrounding normal tissue) samples were added. (C, D) CXCL13 and CXCR5 CDNA quantification in thyroid tissues from $\mathrm{HT}$ patients, GD patients with a high $\left(>5 / 226 \mathrm{~mm}^{2}\right)$ or low number of focal lymphocytic infiltrates and in TA patients (normal and nodular tissue); means \pm S.E.M., ${ }^{*}, * * P<0.005$. 
Table 2 Correlation of CXCL13 and CXCR5 mRNA levels with different parameters in patients with GD.

\begin{tabular}{llc}
\hline & \multicolumn{1}{c}{ CXCL13 mRNA } & CXCR5 mRNA \\
\hline $\begin{array}{l}\text { Number of focal } \\
\text { lymphocytic infiltrates }\end{array}$ & $r=0.678 ; P<0.005 r=0.799 ; P<0.0005$ \\
$\begin{array}{l}\text { Number of germinal } \\
\text { centers }\end{array}$ & $r=0.630, P<0.005 r=0.783 ; P<0.002$ \\
$\begin{array}{l}\text { CD18 mRNA } \\
\text { Level of TPO }\end{array}$ & $r=0.695 ; P<0.002 r=0.662 ; P<0.05$ \\
$\begin{array}{l}\text { autoantibodies } \\
\text { Level of TSH-R }\end{array}$ & $r=0.525, P<0.05 \quad r=0.482 ; P=0.05$ \\
autoantibodies & $r=0.187 ; P>0.05 \quad r=0.212 ; P>0.05$ \\
\hline
\end{tabular}

was lost from a high percentage of thyroid-derived $\mathrm{T}$ - and B-cells whereas CD45 $\mathrm{RO}^{+}$memory lymphocytes increased significantly (not shown). A significantly lower percentage of thyroid-derived T-cells expressed CCR7. Table 3 summarizes all results.

The percentage of lymphocytes expressing CXCR 5 did not vary between normal subjects and patients with GD in peripheral blood. Comparing the percentage of $\mathrm{CD}^{+}$T-cells expressing $\mathrm{CXCR}^{+}$within TLs and PBLs, we found a significantly higher percentage within the thyroid. The percentage of CXCR $5^{+}$within the $\mathrm{CD}^{+}{ }^{+}$T-cell fraction was doubled (Fig. 3). In the peripheral blood, only a minor population of $\mathrm{CD}^{+}{ }^{+} \mathrm{CD} 8^{+}$T-cells expressed the chemokine receptor. This percentage was increased within the thyroid (not shown).

Additionally, we compared the percentages of circulating and thyroid-derived memory $\mathrm{CD} 4^{+}$and $\mathrm{CD}^{+}$ T-cells expressing CXCR5 ( $\mathrm{T}_{\mathrm{FH}^{-}}$-cells). A significantly higher number of thyroid-derived $\mathrm{CD}^{+}$cells were positive for CD45R0 and CXCR5 than the corresponding peripheral cells.

The percentage of $\mathrm{CXCR}^{+}$cells within peripheral and thyroid-derived CD19 ${ }^{+}$B-cells was equally high (Fig. 3). However, a small proportion of CD19 ${ }^{+}$thyroid-derived B-cells did not express the molecule. Also, the density of CXCR5 on peripheral B-cells was higher than on thyroid-derived B-cells.

\section{Discussion}

The chemokine receptor-ligand pair CXCR5 and CXCL13 is essential for the organization of lymphoid follicles in normal secondary lymphoid organs $(1-3$, 28). Here, we describe the correlation between CXCR5 and CXCL13 mRNA expression and the number of lymphocytic infiltrates and ectopic GCs in thyroid tissue affected by autoimmunity.

CXCR 5 mRNA levels within thyroid tissues exclusively represent the extent of lymphocytic infiltration, and thus correlate with the number of lymphocytic infiltrates and GC as well as CD18 mRNA levels. Apart from CXCR 5 mRNA quantification, we examined CXCR 5 at the cellular level in flow cytometry. CXCR $5^{+}$ T-cells constitute a minor fraction within peripheral blood memory $\mathrm{CD}^{+}{ }^{+} \mathrm{T}$-cells. These cells represent the pool of recent memory cells with a non-polarized phenotype and a recent history of immune activation $(6,29)$ and might play an immune surveillance function by disseminating 'antigen-priming' information from the origin-inflamed secondary (or ectopic?) lymphoid tissue to alternative tissues previously not involved (7). It is unknown whether this peripheral memory $\mathrm{CD} 4^{+} \mathrm{CXCR}^{+}$T-cell pool is relatively constant or increases during intensified immune responses. We found no significant differences between GD patients and normal subjects regarding the percentage of these cells in the peripheral blood. In contrast, the percentage of memory $\mathrm{CD} 4^{+} \mathrm{CXCR} 5^{+}$cells is significantly higher within thyroid-derived compared with peripheral T-lymphocytes from the same GD patient. In normal secondary lymphoid tissues, these cells possess three options for further development (6). First, the cells may be recruited into B-cell follicles which selectively express CXCL13 by means of CXCR 5 expression. Here, the memory $\mathrm{CD} 4^{+} \mathrm{CXCR} 5^{+}$cells efficiently support the production of immunoglobulins, thus characterized as $\mathrm{T}_{\mathrm{FH}}(8,30)$. Secondly, if not recruited to the B-cell zone, the cells reside in the T-cell zone and differentiate into Th1 or Th 2 cells but lose CXCR 5. Thirdly, these $\mathrm{CXCR}^{+}$cells have the option of exiting the lymphoid tissue to form the peripheral pool of recent memory $\mathrm{CD} 4^{+}$T-cells as mentioned above. Whether memory $\mathrm{CD} 4^{+} \mathrm{CXCR}^{+}$cells within ectopic thyroid follicles undergo the same development as in normal secondary follicles is unclear.

Our result revealing a higher percentage of $\mathrm{CD} 3^{+} \mathrm{CXCR}^{+}$cells within the thyroid compared with the periphery differs from that of Armengol et al. (19), who did not find any difference between the two

Table 3 CXCR5 expression of TLs and PBLs from patients with GD $(n=10)$ and normal controls $(n=10)$ analyzed by flow cytometry. None of the differences in PBLs between the controls and GD patients were significant. Means \pm S.E.M.

\begin{tabular}{|c|c|c|c|c|}
\hline Gating on & & TL, GD patients $(n=10)$ & PBL, GD patients $(n=10)$ & PBL, controls $(n=10)$ \\
\hline $100 \% \mathrm{CD}^{+}$ & $\begin{array}{l}\mathrm{CXCR}^{+} \\
\mathrm{CCR}^{+} \\
\mathrm{CD}^{+} \mathrm{L}^{+} \\
\mathrm{CD}^{+}{ }^{+} \mathrm{CD} 45 \mathrm{R}^{+} \mathrm{CXCR}^{+}\end{array}$ & $\begin{array}{l}20.5 \pm 2.0^{*}(P=0.0232) \\
26.3 \pm 3.6^{*}(P=0.0286) \\
30.7 \pm 6.8^{*}(P=0.007) \\
18.0 \pm 3.2^{*}(P=0.0260)\end{array}$ & $\begin{array}{r}11.1 \pm 1.5 \\
66.3 \pm 7.0 \\
80.4 \pm 2.6 \\
8.3 \pm 1.5\end{array}$ & $\begin{array}{r}8.8 \pm 1.2 \\
67.5 \pm 5.8 \\
77.1 \pm 2.8 \\
6.4 \pm 0.5\end{array}$ \\
\hline $100 \% \mathrm{CD}^{+} 9^{+}$ & $\mathrm{CD} 2 \mathrm{~L}^{+}$ & $21.3 \pm 5.9 *(P=0.0086)$ & $87.1 \pm 5.9$ & $91.8 \pm 1.8$ \\
\hline
\end{tabular}

* Significant differences between TL and PBL in patients with GD percentage of labeled cells. 
PBL

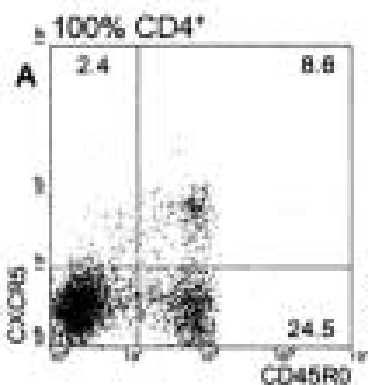

TL
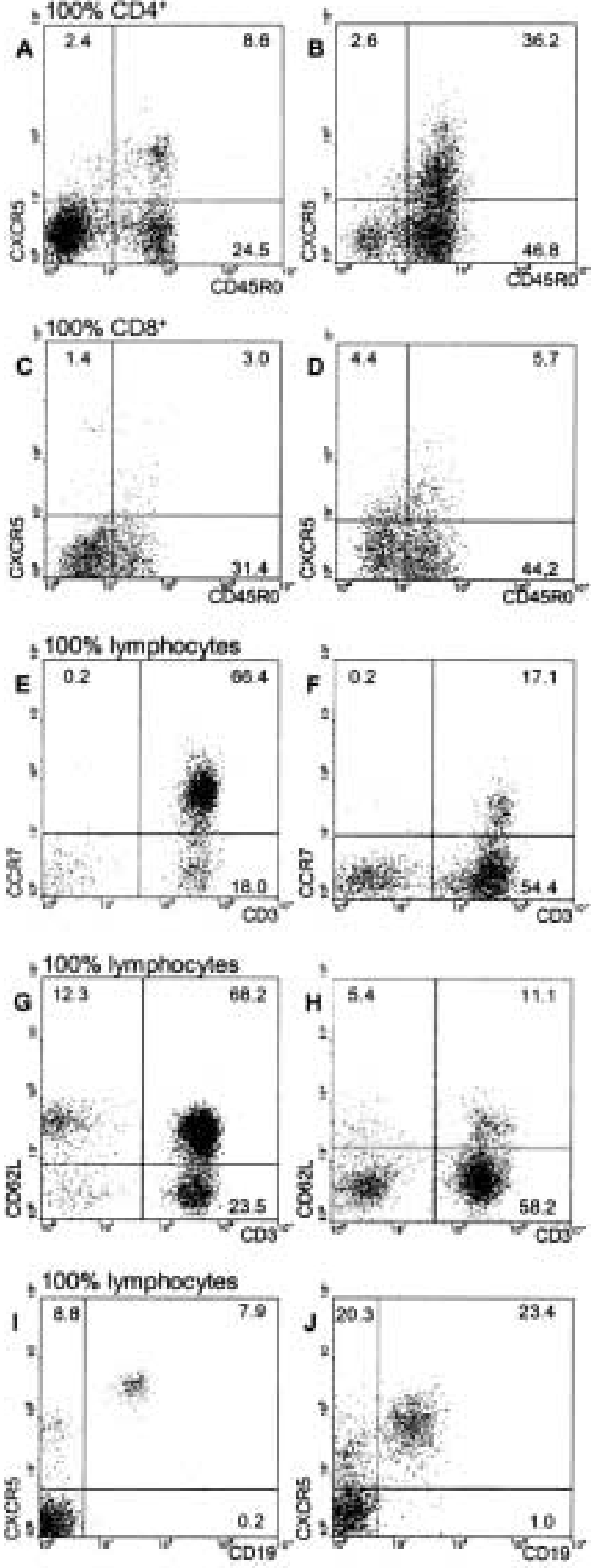

Figure 3 Percentage of $\mathrm{CXCR}^{+}, \mathrm{CD}^{+} 2^{+}$or $\mathrm{CCR} 7^{+}$cells from one typical GD patient in PBLs (A, C, E, G, I) and TLs (B, D, F $H, J)$ analyzed by flow cytometry within $100 \% \mathrm{CD}^{+}(\mathrm{A}, \mathrm{B}), 100 \%$ $\mathrm{CD}^{+}(\mathrm{C}, \mathrm{D})$ cells, or lymphocytes using directly labeled monoclonal antibodies. compartments. We isolated TLs mechanically, whereas Armengol et al. digested thyroid tissue enzymatically. That group itself showed modulation of surface receptors after digestion. We demonstrated that some of the chemokine receptors were unfavorably influenced by enzymatic separation procedures (18). We could dispel the suspicion that mechanically isolated lymphocytes might be PBLs since our TLs had lost expression of CD62L and CCR7 and typically contained a higher percentage of memory CD45R0 ${ }^{+}$cells compared with PBLs (31). Also, we could not confirm the result reached by Armengol et al. (19) that the percentage of circulating $\mathrm{CCR}^{+}$lymphocytes was significantly reduced in GD patients compared with controls.

Although CXCR 5 is expressed on all peripheral Bcells in GD patients as in normal subjects (4), the percentage of thyroid-derived B-cells bearing CXCR 5 was at nearly $90 \%$. The small $\mathrm{CD} 19^{+} \mathrm{CXCR} 5^{-}$B-cell population may represent plasma cells that downregulate CXCR 5, while copious immunoglobulin synthesis and secretion is induced (32).

Our CXCL13 data confirm (i) results from Armengol et al. (19) of increased CXCL13 mRNA levels within thyroids with high numbers of lymphocytic infiltrates often forming lymphoid ectopic follicles and (ii) results from other non-lymphoid tissues containing these structures. In salivary gland tissue from Sjogren's syndrome patients, CXCL13 was expressed within lymphoid aggregates that shared many structural features with normal GCs $(11,33)$. CXCL13 is produced and accumulated in irregular lymphoid aggregates in ulcerative colitis lesions (12) and in Helicobacter pylori-induced, mucosal-associated lymphoid tissue and gastric lymphoma (34). CXCL13 and tumor necrosis factor family member lymphotoxin- $\beta$ are both strongly involved in GC formation, and have been described as predictors for the recruitment of follicular dendritic cells and the formations of GCs in rheumatoid arthritis $(9,10,35)$. We found significant differences between nodules and surrounding tissue in TA thyroids regarding CXCR 5 and CXCL13 mRNA levels. In most cases, only very few lymphocytes, if any, could be detected, and no CD18 mRNA could be measured within the nodules, which explains the usually negative results. However, we found slight basal CXCL13 mRNA expression in normal thyroid without focal lymphocytic infiltrates. Here, dendritic cells were relatively scare (36). In addition to these rare cells, other cell types may contribute to the signal. Non-stimulated thyrocytes as well as thyroid-derived fibroblasts were CXCL13 mRNA-negative (not shown). However, stimulated cells as well as endothelial and C-cells were not examined for CXCL13 mRNA expression.

All these data suggest that constitutive chemokines like CXCL13 and their receptors not only contribute to lymphoid homing in normal tissues, but also play a critical role in the persistence of chronic lymphocytic infiltration and establishing GCs at unusual sites such 
as the thyroid. Here, by creating a local microenvironment supportive of focal B-cell aggregation and differentiation with structural features that are remarkably similar to GCs, CXCL13 and CXCR 5 contribute to the production of TPO autoantibodies classically associated with GD. Our data confirmed the studies showing (i) selective binding of the two autoantigens TPO and thyroglobulin in the ectopic GCs, indicating that GC formation was committed to these self antigens (17), and (ii) a correlation between TPO antibodies and lymphocytic infiltration (37). When GD tissues were analyzed and compared with TA thyroid tissues, TBII antibodies correlated with CXCR5 and CXCL13 mRNA levels as shown for CXCL13 in the study of Armengol et al. (19). However, CXCR5 and CXCL13 mRNA levels were not related to TSH-R antibody formation within the group of GD patients, suggesting that B-cells producing these antibodies are not located in formatted structures such as focal infiltrates or ectopic follicles or are partially located outside the thyroid. TBII might not be produced exclusively by the thyroid itself. As shown in a short-term culture system, lymphocytes from cervical lymph nodes, thyroid and bone marrow contributed to thyroid autoantibody production (38). In the study by Chiovato et al. (39), the disappearance of thyroid antibodies after surgical ablation of the thyroid was gradual and continued without any sharp decrease after the operation. This pattern of thyroid antibody disappearance suggests that extrathyroidal tissues contribute to the production of thyroid antibodies, at least in long-standing autoimmune thyroid diseases. Memory cells within peripheral immune organs can be triggered to produce thyroid antibodies upon antigen stimulation (40). Furthermore, the first thyroid-draining lymph nodes during the development of intrathyroidal lymphoid tissue in BB-DP rats showed an early production of anti-thyroglobulin antibodies, which later switched to the thyroid when intrathyroidal lymphoid tissue occurred (41). Here, time and chronicity of the autoimmune process determines the presence of extrathyroidal sites of autoantibody synthesis. Moreover, microsomal (TPO) antibody titers seem to reflect the intensity of the intrathyroidal autoimmune process in GD better than TSH-R antibodies (37).

The question is whether or not ectopic thyroid follicles mimic normal secondary lymphoid follicles in all aspects $(19,42)$. Here, we showed that the expression of CXCR 5 and CXCL13 in autoimmune thyroids is remarkably similar to that in normal lymphoid tissues. Furthermore, as in normal lymph nodes, thyroidderived lymphocytes lost the combination code for entry of T- and B-cells, the expression of CD62L and CCR7. However, the lack of concordance between rearrangements in $\mathrm{CD} 20^{+}$B-cells and plasma cells in rheumatoid synovium and the lack of identical rearrangements in adjacent B-cell clusters in Sjogren's syndrome suggest that the GC-like structures seen in these autoimmune diseases mimic many, but not all of the functional features of classic GCs (42). Many of the necessary microenvironmental features required to generate functional GC-like structures exist in chronically inflamed non-lymphoid tissue, but not all of them are present; this might lead to the aberrant production of high-affinity antibodies with autoreactive properties. The question arises as to which factors ultimately control this process, as not all GD tissues showed high CXCL13 and CXCR5 mRNA levels or high numbers of lymphocytic infiltrates and GCs. Perhaps the different host response patterns suggest a probable contribution of genetic risk factors.

\section{References}

1 Forster R, Mattis AE, Kremmer E, Wolf E, Brem G \& Lipp M. A putative chemokine receptor, BLR1, directs B cell migration to defined lymphoid organs and specific anatomic compartments of the spleen. Cell 199687 1037-1047.

2 Ansel KM, Ngo VN, Hyman PL, Luther SA, Forster R, Sedgwick JD, Browning JL, Lipp M \& Cyster JG. A chemokine-driven positive feedback loop organizes lymphoid follicles. Nature $2000 \mathbf{4 0 6}$ 309-314.

3 Voigt I, Camacho SA, de Boer BA, Lipp M, Forster R \& Berek C. CXCR5-deficient mice develop functional germinal centers in the splenic T cell zone. European Journal of Immunology 200030 560-567.

4 Legler DF, Loetscher M, Roos RS, Clark-Lewis I, Baggiolini M \& Moser B. B cell-attracting chemokine 1, a human CXC chemokine expressed in lymphoid tissues, selectively attracts B lymphocytes via BLR1/CXCR5. Journal of Experimental Medicine $1998 \mathbf{1 8 7}$ 655-660.

5 Forster R, Emrich T, Kremmer E \& Lipp M. Expression of the Gprotein-coupled receptor BLR1 defines mature, recirculating B cells and a subset of T-helper memory cells. Blood $1994 \mathbf{8 4}$ 830-840.

6 Schaerli P, Loetscher P \& Moser B. Cutting edge: induction of follicular homing precedes effector Th cell development. Journal of Immunology $2001 \mathbf{1 6 7} 6082-6086$.

7 Moser B, Schaerli P \& Loetscher P. CXCR5(+) T cells: follicular homing takes center stage in T-helper-cell responses. Trends in Immunology 200223 250-254.

8 Breitfeld D, Ohl L, Kremmer E, Ellwart J, Sallusto F, Lipp M \& Forster R. Follicular B helper T cells express CXC chemokine receptor 5, localize to $\mathrm{B}$ cell follicles, and support immunoglobulin production. Journal of Experimental Medicine $2000 \mathbf{1 9 2}$ 1545-1552.

9 Shi K, Hayashida K, Kaneko M, Hashimoto J, Tomita T, Lipsky PE, Yoshikawa H \& Ochi T. Lymphoid chemokine B cell-attracting chemokine-1 (CXCL13) is expressed in germinal center of ectopic lymphoid follicles within the synovium of chronic arthritis patients. Journal of Immunology $2001 \mathbf{1 6 6}$ 650-655.

10 Weyand CM \& Goronzy JJ. Ectopic germinal center formation in rheumatoid synovitis. Annals of the New York Academy of Sciences 2003987 140-149.

11 Amft N, Curnow SJ, Scheel-Toellner D, Devadas A, Oates J, Crocker J, Hamburger J, Ainsworth J, Mathews J, Salmon M, Bowman SJ \& Buckley CD. Ectopic expression of the B cell-attracting chemokine BCA-1 (CXCL13) on endothelial cells and within lymphoid follicles contributes to the establishment of germinal center-like structures in Sjogren's syndrome. Arthritis and Rheumatism $2001 \mathbf{4 4} 2633-2641$.

12 Carlsen HS, Baekkevold ES, Johansen FE, Haraldsen G \& Brandtzaeg P. B cell attracting chemokine 1 (CXCL13) and its receptor CXCR 5 are expressed in normal and aberrant gut associated lymphoid tissue. Gut 200251 364-371. 
13 Warford A, McLachlan SM, Malcolm AJ, Young ET, Farndon JR \& Rees Smith B. Characterization of lymphoid cells in the thyroid of patients with Graves' disease. Clinical and Experimental Immunology 198457 626-632.

14 Jeong HJ, Lee MK, Choi IJ \& Lee YB. Distribution of lymphocytic subpopulations infiltrated in thyroid glands of Graves' disease. Yonsei Medical Journal $198930118-124$.

15 Ashhab Y, Dominguez O, Sospedra M, Roura-Mir C, Lucas-Martin A \& Pujol-Borrell R. A one-tube polymerase chain reaction protocol demonstrates CC chemokine overexpression in Graves' disease glands. Journal of Clinical Endocrinology and Metabolism 199984 2873-2882.

16 Simchen C, Lehmann I, Sittig D, Steinert M \& Aust G. Expression and regulation of regulated on activation, normal $\mathrm{T}$ cells expressed and secreted in thyroid tissue of patients with Graves' disease and thyroid autonomy and in thyroid-derived cell populations. Journal of Clinical Endocrinology and Metabolism 199985 4764.

17 Armengol MP, Juan M, Lucas-Martin A, Fernandez-Figueras MT, Jaraquemada D, Gallart T \& Pujol-Borrell R. Thyroid autoimmune disease: demonstration of thyroid antigen-specific $B$ cells and recombination-activating gene expression in chemokine-containing active intrathyroidal germinal centers. American Journal of Pathology $2001159861-873$.

18 Aust G, Sittig D, Steinert M, Lamesch P \& Lohmann T. Graves' disease is associated with an altered CXCR3 and CCR5 expression in thyroid-derived compared to peripheral blood lymphocytes. Clinical and Experimental Immunology $2002 \mathbf{1 2 7}$ 479-485.

19 Armengol MP, Cardoso-Schmidt CB, Fernandez M, Ferrer X, Pujol-Borrell R \& Juan M. Chemokines determine local lymphoneogenesis and a reduction of circulating $\operatorname{CXCR} 4(+) \mathrm{T}$ and CCR7 $\mathrm{B}$ and $\mathrm{T}$ lymphocytes in thyroid autoimmune diseases. Journal of Immunology $2003 \mathbf{1 7 0} 6320-6328$.

20 Aust G, Becherer L, Sittig D, Lamesch P \& Schmücking E. The role of CXCR 5 and its ligand CXCL13 in the compartmentalization of lymphocytes in thyroids affected by Grave's disease. In Sixth European Congress of Endocrinology 26-30.4.2003, Lyon, France 2003, [abstract].

21 Garcia-Lopez MA, Sancho D, Sanchez-Madrid F \& Marazuela M. Thyrocytes from autoimmune thyroid disorders produce the chemokines IP-10 and Mig and attract CXCR3 + lymphocytes. Journal of Clinical Endocrinology and Metabolism 200186 5008-5016.

22 Aust G, Steinert M, Boltze C, Kiessling S \& Simchen C. GRO-alpha in normal and pathological thyroid tissues and its regulation in thyroid-derived cells. Journal of Endocrinology $2001 \quad \mathbf{1 7 0}$ 513-520.

23 Kemp EH, Metcalfe RA, Smith KA, Woodroofe MN, Watson PF \& Weetman AP. Detection and localization of chemokine gene expression in autoimmune thyroid disease. Clinical Endocrinology $200359207-213$.

24 Aust G, Steinert M, Kiessling S, Kamprad M \& Simchen C. Reduced expression of Stromal-derived factor 1 in autonomous thyroid adenomas and its regulation in thyroid-derived cells. Journal of Clinical Endocrinology and Metabolism $2001 \quad \mathbf{8 6}$ $3368-3376$

25 Pritchard J, Horst N, Cruikshank W \& Smith TJ. Igs from patients with Graves' disease induce the expression of T cell chemoattractants in their fibroblasts. Journal of Immunology $2002 \mathbf{1 6 8}$ 942-950.

26 Köhler T, Schill C, Deininger MW, Krahl R, Borchert S, Hasenclever D, Leiblein S, Wagner $\mathrm{O} \&$ Niederwieser $\mathrm{D}$. High Bad and Bax mRNA expression correlate with negative outcome in acute myeloid leukemia (AML). Leukemia 200216 $22-29$.

27 Petrasch S, Perez-Alvarez C, Schmitz J, Kosco M \& Brittinger G. Antigenic phenotyping of human follicular dendritic cells isolated from nonmalignant and malignant lymphatic tissue. European Journal of Immunology $1990 \mathbf{2 0} 1013-1018$.

28 Muller G, Hopken UE, Stein H \& Lipp M. Systemic immunoregulatory and pathogenic functions of homeostatic chemokine receptors. Journal of Leukocyte Biology $2002 \mathbf{7 2}$ $1-8$.

29 Sallusto F, Kremmer E, Palermo B, Hoy A, Ponath P, Oin S, Forster R, Lipp M \& Lanzavecchia A. Switch in chemokine receptor expression upon TCR stimulation reveals novel homing potential for recently activated T cells. European Journal of Immunology $1999292037-2045$.

30 Moser B \& Ebert L. Lymphocyte traffic control by chemokines: follicular B helper T cells. Immunology Letters $2003 \mathbf{8 5}$ 105-112.

31 Ishikawa N, Eguchi K, Ueki Y, Nakashima M, Shimada H, Ito K \& Nagataki S. Expression of adhesion molecules on infiltrating $\mathrm{T}$ cells in thyroid glands from patients with Graves' disease. Clinical and Experimental Immunology 199394 363-370.

32 Calame KL, Lin KI \& Tunyaplin C. Regulatory mechanisms that determine the development and function of plasma cells. Annual Review of Immunology $200321205-230$.

33 Salomonsson S, Larsson P, Tengner P, Mellquist E, Hjelmstrom P \& Wahren-Herlenius M. Expression of the B cell-attracting chemokine CXCL13 in the target organ and autoantibody production in ectopic lymphoid tissue in the chronic inflammatory disease Sjogren's syndrome. Scandinavian Journal of Immunology 2002 $55336-342$.

34 Mazzucchelli L, Blaser A, Kappeler A, Scharli P, Laissue JA, Baggiolini M \& Uguccioni M. BCA-1 is highly expressed in Helicobacter pylori-induced mucosa-associated lymphoid tissue and gastric lymphoma. Journal of Clinical Investigation $1999 \mathbf{1 0 4}$ $49-54$.

35 Takemura S, Braun A, Crowson C, Kurtin PJ, Cofield RH, O'Fallon WM, Goronzy JJ \& Weyand CM. Lymphoid neogenesis in rheumatoid synovitis. Journal of Immunology $2001 \mathbf{1 6 7}$ 1072-1080.

36 Kabel PJ, Voorbij HAM, De Haan-Meulman M, van der Gaag RD \& Drexhage HA. Intrathyroidal dendritic cells. Journal of Clinical Endocrinology and Metabolism 198866 199-207.

37 Paschke R, Vogg M, Swillens S \& Usadel KH. Correlation of microsomal antibodies with the intensity of the intrathyroidal autoimmune process in Graves' disease. Journal of Clinical Endocrinology and Metabolism 199377 939-943.

38 Weetman AP, McGregor AM, Wheeler MH \& Hall R. Extrathyroidal sites of autoantibody synthesis in Graves' disease. Clinical and Experimental Immunology 198456 330-336.

39 Chiovato L, Latrofa F, Braverman LE, Pacini F, Capezzone M, Masserini L, Grasso L \& Pinchera A. Disappearance of humoral thyroid autoimmunity after complete removal of thyroid antigens. Annals of Internal Medicine 2003139 346-351.

40 McLachlan SM, Fawcett J, Atherton MC, Thompson P, Baylis P \& Smith BR. Thyroid autoantibody synthesis by cultures of thyroid and peripheral blood lymphocytes. II Effect of thyroglobulin on thyroglobulin antibody synthesis. Clinical and Experimental Immunology 198352 620-628.

41 Voorby HA, Kabel PJ, de Haan M, Jeucken PH, van der Gaag RD, de Baets MH \& Drexhage HA. Dendritic cells and class II MHC expression on thyrocytes during the autoimmune thyroid disease of the BB rat. Clinical and Immunological Immunopathology 1990 $559-22$.

42 Weyand CM, Kurtin PJ \& Goronzy JJ. Ectopic lymphoid organogenesis: a fast track for autoimmunity. American Journal of Pathology 2001159 787-793.

Received 25 July 2003

Accepted 11 November 2003 